\title{
Online Resources for the History of Out-of-Body Experiences and Death-Related Phenomena
}

\author{
Carlos S. Alvarado, Ph.D. \\ University of Virginia
}

\begin{abstract}
Google Books is a digital library covering out of print publications about a variety of topics, among them materials relevant for a history of discussions, observations, and collections of cases of out-of-body experiences and death-related phenomena such as near-death experiences, deathbed visions, and apparitions. In this article, I provide examples of copyright-free and cost-free sources from Google Books that investigators of near-death and related phenomena can download and change into plain text; in many cases, I include passages that give readers a sense of the richness of these sources for both a historical and a contemporary understanding of neardeath and related phenomena. Examples of books include Johann Engelbrecht's The Divine Visions of John Engelbrecht (1780), Augustine Calmet's The Phantom World (1850), Henri Roger Gougenot de Mousseaux's Les hauts phénomènes de la magie (1864), Edward H. Clarke's Visions (1878), William H. Harrison's Spirits Before Our Eyes (1879), and Frederic W. H. Myers's Human Personality and Its Survival of Bodily Death (1903). Examples of articles include those written by such authors as Ernesto Bozzano, Francis Power Cobbe, James H. Hyslop, Duncan MacDougall, Frank Podmore, and A. S. Wiltse.
\end{abstract}

KEY WORDS: Google Books; bibliography; out-of-body experiences; neardeath experiences; death phenomena; apparitions.

Of relevance to many readers of the Journal of Near-Death Studies is the history of recordings of cases of, observations about, and

Carlos S. Alvarado, Ph.D., is Scholar in Residence at Atlantic University. The author thanks Nancy L. Zingrone, Ph.D., and Janice Holden, Ed.D., for useful editorial suggestions for the improvement of this paper. Reprint requests should be addressed to Dr. Alvarado at Atlantic University, 215 67th Street, Virginia Beach, VA 23451; email: carlos.alvarado@atlanticuniv.edu. 
discussions about out-of-body experiences (OBEs), near-death experiences (NDEs), death-bed visions, apparitions, and related topics. That history is reflected in many bibliographical sources (for overviews see the works of Alvarado, 2005, 2009a, 2009c; Rogo, 1978; and Zaleski, 1987). At one time, many of these sources were difficult to find, but with the development of virtual libraries, several of these sources have become easily available. An example of one of these libraries, and the focus of this paper, is Google Books. In previous papers I have discussed the holdings of this library about such topics as mesmerism (Alvarado, 2008a), dissociation (2008b), and the literatures of spiritualism and psychical research (Alvarado, 2007a, 2007b). In this paper I would like to call to the attention of readers of the Journal this bibliographical resource containing many relevant materials about the topics in question.

Google Books (http://books.google.com/), formed mainly of multilingual copyright-free books, journals, and magazines scanned in PDF format from many libraries, is available without charge. Some of the participating libraries are those of many universities, including Complutense, Cornell, Harvard, and Princeton, and of other institutions such as Bayerische Staats Bibliothek, Biblioteca de Catalunya, Bibliothèque Municipale de Lyon, and the New York Public Library. Although Google Books can be used from many countries, I have heard from some colleagues outside the United States that they have not been able to access the library.

For the purpose of this article I am focusing on the copyright-free articles and books that are available in full text and can be downloaded and changed into plain text. The rest of the collection consists of materials that have a limited preview, mainly sections of books that are not copyright-free and books that are not available at all. The latter category is divided into "snippet view," with basic publication and other general information, and "no preview available," with a summary and publication information. All the entries include links to booksellers and to WorldCat (http://www.worldcat.org/), an online network of the content and services of thousands of libraries. Also, although some copyright controversies are ongoing, they are beyond the scope of this paper in which my focus is copyright-free literature.

A search engine allows users to locate materials using key terms, titles, and proper names. Furthermore, users can perform searches inside particular documents. To illustrate the usefulness of this 
virtual library I will mention some examples from its holdings taken from the thousands of relevant materials in the collection. I chose these examples based on my assessment of which ones would be of greatest interest to readers of this Journal and of which selections together would best illustrate the scope of sources available through Google Books. In addition readers will likely recognize in the excerpts topics still addressed in the contemporary OBE and near-death phenomena literature. I have translated some of these excerpts from French sources.

Whereas non-professionals in the field of near-death studies are likely to find the Google Books resources of great interest, professionals in the field are likely to find them of vital importance for at least two reasons. First, these old materials are of practical use for such issues as the generation of ideas for research and to obtain examples of cases for the purpose of illustrating phenomena. Second, they provide the knowledge and perspective that enables academics and other professionals to understand the history of the death-related topics discussed herein. This history includes events and ideas directly relevant to the interests of current researchers as well as past developments and ideas seemingly unrelated to current concerns.

\section{Out-of-Body Experiences}

The digital library has several interesting discussions about OBEs. In his Natural History, Pliny the Elder (1890) wrote that

the soul of Hermotinus of Clazomenae was in the habit of leaving his body, and wandering into distant countries, whence it brought back numerous accounts of various things, which could not have been obtained by any one but a person who was present. The body, in the meantime, was left apparently lifeless .... At last, however, his enemies, the Cantharidae ... burned the body, so that the soul, on its return, was deprived of its sheath, as it were. (p. 210)

Some of the materials in the library have information about OBEs taking place while individuals were mesmerized. Two examples are Joseph W. Haddock's Somnolism \& Psycheism (1851) and Louise Alphonse Cahagnet's The Celestial Telegraph (1851). The latter wrote that his mesmerized subject Bruno Binet said: "In the state I am now ... I am out of my body, I perceive it seated on the chair; I walk about in my room without being seen or felt by you whom I touch" (p. 19). 
Another example is the OBEs descriptions of French somnambule Alexis Didier (1856). One of them read:

The whole Universe is in front of me; and I can transport from a pole to another with the speed of lightning; I can talk with the Caffres, walk in China, descend on the mines of Australia, enter the harem of a sultan in less than an hour, without fatigue .... (p. 15; my translation).

Discussing mesmerism in his book Du magnétisme et des sciences occultes (1860), lawyer André Saturnin Morin expressed skepticism about the idea that the soul could separate from the body. Such an occurrence, he believed, would end in death. Perceptions of distant places during somnambulistic voyages were considered by him to be imaginary (pp. 261-262). Morin saw somnambulism as a variety of sleep in which the person could confuse the real with the unreal. In his words:

The somnambule, while the crisis lasts, equally confuses illusion and reality. Because while awake he loses recollection, he is incapable of rectifying the errors into which he falls using his own judgment; so that with a new crisis, he is led towards the same topic ..., he figures, as during the first time, that he really travelled to the places visited by his thought; he will have the same impressions than those of the first peregrinations; he will not hesitate to likewise declare real one or the other (p. 262; my translation).

Years later Charles Richet (1887) took a similar position regarding somnambulistic OBEs. He argued that it would be a "mistake to believe that such dreams are real, and that the vision corresponds to the ex-istence of exterior things" (p. 178).

Many accounts portray OBEs taking place in normal circumstances such as standing up (Gurney, Myers \& Podmore, 1886, Vol. 2, p. 85, footnote). In his autobiography Incidents in My Life, medium D. D. Home (1863, pp. 43-47) wrote about an elaborate OBE he had while he was thinking about death and God. The collection also contains accounts of OBEs presented by Pierre Piobb in L'année occultiste et psychique (1908, pp. 205-221) and reports of a variety of tests including perceptual and physical phenomena conducted by Hector Durville (1908a, 1908b, 1908c) on what he referred to as the "doubling of the human body."

Other cases appear in the fourth chapter of J. Arthur Hill's Man is a Spirit (1918). According to Hill:

We seem to be spirits in prison, either for former sins or for our discipline and instruction, or as a necessary part of our growth .... 
'The shell is needed till the bird is hatched,' as the Russian proverb says, and perhaps our cabined condition here is the equivalent of that early embryonic stage. But we seem to be less hermetically sealed off, for some few of us, even while 'alive,' can get out of our shell and temporarily live in a wider world, with immense increase of freedom and sense of well-being. (p. 67)

Geologist William Denton (1872) stated in his book, Radical Discourses on Religious Subjects, that individuals having the gift of psychometry also tended to have the experience of being out of their bodies. As he wrote about his sister, wife, and son:

Mrs. Cridge, Mrs. Denton, and my son Sherman, travel spiritually with great ease, and describe with great accuracy distant localities never visited by them, and sometimes unknown to all persons present. They describe themselves as being there, to all appearance, in the body, so that they can see its different parts; the spiritual body being as real to spiritual sight as the physical body is to the physical eye, and quite as much so to the touch. They can hear, see, feel, taste, smell, and, in short, exercise every sense, much more perfectly than if present in the body .... (pp. 128-129)

Henri Roger Gougenot de Mousseaux, known for his anti-Semitic and anti-spiritist writings, expressed skepticism about "animic voyages" in his book Les hauts phénomènes de la magie (1864). He believed that "the separation of the soul from the body, or of two parts of the living man, is death ..." (p. 101; my translation), and, consequently, an illusion. English spiritualist William H. Harrison also discussed this topic in his book Spirits Before Our Eyes (1879). Harrison accepted that the spirit could travel out of the body and be seen at a distance by others. In his view, when someone is "in a state of sleep or trance his spirit can sometimes travel without his being any the worse for the achievement, but he does not usually remember in his normal condition what he has seen with spiritual eyes ...." (p. 201). But Harrison wondered if some experiences in which the traveler witnessed events at a distance that were later found to be true could be explained through clairvoyance or thought-reading not requiring the exit of a spirit from the physical body.

The virtual library has some discussions of the subject by members of the well-known Society for Psychical Research (SPR). For example, Edmund Gurney wrote: "The sense of being 'out of the body' ... is a known form of pathologic experience, or,-as I should regard it—of hallucination" (Gurney, Myers, \& Podmore, 1886, Vol. 1, p. 288). Gurney's comments referred to OBEs with no reported veridical 
features. Writing about veridical cases, particularly those few reciprocal apparitions in which the experiencer felt oneself to be at a location other than that of the physical body and one or more others perceived the experiencer as an apparition, Gurney defended the idea that the experience consisted of telepathic contact in which "each of the parties might receive a telepathic impulse from the other, and so each be at once agent and percipient" (Gurney et al., 1886, Vol. 2, p. 153). Other SPR members supported this idea (Podmore, 1894, pp. 301-302; Sidgwick, 1891, pp. 45-46).

Another SPR member, classical scholar and psychical researcher Frederic W. H. Myers, wrote in Human Personality and Its Survival of Bodily Death (1903) about "psychical excursion," which was said to involve "some kind of perception as from a new standpoint ...." (Vol. 1, p. 230). He wrote further:

If there be spiritual excursion to a particular point of space, it is conceivable that this should involve not only the migrant spirit's perception from that point, but also perception of that point by persons materially present near it. That point may become a phantasmogenetic centre, as well as a centre of outlook. In plain words, if A has spiritually invaded B's room, and there sees B, B on his part may see A symbolically standing there; and C and D if present may see A as well. (Vol. 1, p. 232)

The collection also has discussions of astral projection and the concept of doubles in such varied works as Adolphe D'Assier's Posthumous Humanity (1883/1887), Annie Besant's The Seven Principles of Man (1892), Charles W. Leadbeater's The Astral Plane (1895), Henry Olcott's Old Diary Leaves (1895), William Stead's "Two Doubles I Have Seen" (1896), and Hereward Carrington's Your Psychic Powers and How to Develop Them (1920).

\section{Near-Death Experiences}

An account from antiquity was the case of Thespesius of Soli narrated by Plutarch, who described how this person got out of his body after a fall from which he recovered in three-days time (Schilleto, 1888, pp. 357-365). In The Phantom World, biblical scholar and Benedictine Abbot Augustine Calmet (1850, Vol. 2, chapters 49, 53, 55) mentioned several previously published accounts of NDEs coming from antiquity. The collection also has several interesting accounts from the middle ages, such as The Revelation of the Monk of Evesham (Arber, 1869). 
In another account recorded by the Venerable Bede, a holy man named Fursey built a monastery in Suffolk:

There, falling sick ... he fell into a trance, and quitting his body from the evening till the cock crew, he was found worthy to behold the choirs of angels, and to hear the praises which are sung in heaven. (Gibs, 1847, p. 139)

Two other cases are briefly mentioned in a discussion of the AngloSaxon Church. Servant Drihthelm and priest Furseus both fell sick and died and had a variety of experiences after having been taken by angels (Thorpe, 1846, pp. 335-349).

An interesting account of an elaborate NDE taking place in the $17^{\text {th }}$ century was that of German visionary Johann Engelbrecht. In 1622, coming one day from Church feeling great sorrow, he spent the next eight days without eating much except for some bread and wine. Engelbrecht felt great pains, screamed loudly, and eventually lost the sensation of his body. According to his account, printed with old spelling and capitalization:

Then was I ... taken up with my whole body; and it was tranfported and carried away with far more Swiftnefs than any arrow can fly .... My soul then having been thus fet down before Hell, I there faw ... a dreadful, great, and thick Darknefs .... Amidft the Darknefs, I heard a Multitude of dreadful, howling Voices .... Being thus now before Hell, many Thoufand Devils furrounded and preffed hard upon me, being very defirous to have me alfo into Hell along with them .... [He prayed to God and] immediately the Darknefs vanifhed, the Stench was gone, the Voices were hufhed and ftill; and the Holy Ghoft, appearing to me in the Shape of a Man in white, placed me upon a Chariot of Gold, ... and conveyed me into the radiant and fplendorous Light of the divine Glory .... I there faw in Spirit the Choir of the holy Angels, the Choir of the Prophets and Apoftles .... the holy Angels, in the Form or Shape of a Multitute of Flames of Fire; the Souls of Believers in the Shape of a Multitude of glittering, or luminous Sparkles; God's Throne in the Shape, on under the Appearance, of a great Splendor .... And as in Hell I fmelt an horrible Stench; fo did I alfo again fmell in Heaven an immeafurable fweet, agreeable, and lovely Fragance .... (Engelbrecht, 1780, pp. 58-61)

Typical of many visionary experiences during this period, Engelbrecht affirmed the purpose of his vision was to bear witness. He was told to inform people that they must believe in Jesus Christ and repent their sins. Years later, French physician and student of hallucination Alexandre Brierre de Boismont mentioned Engelbrecht's experience in his Hallucinations: Or, the Rational History of Apparitions, Visions, 
Dreams, Ecstasy, Magnetism, and Somnambulism (1853). This author saw Englebrecht's report as an example of ecstasy, or a "nervous excitability" affected by fanatic ideas, and "by a belief which brings in its train either ardent hopes or strong fears" (p. 214).

Other accounts can be found in Life of the Rev. William Tennent (1848), and in John Scott's Scenes Beyond the Grave: Trance of Marietta Davis (1859). A later account was A. S. Wiltse's "A Case of Typhoid Fever with Subnormal Temperature and Pulse" (1889), which continues to be cited to this day.

The virtual library also has writings about panoramic memory during drowning (Clarke, 1833, pp. 82-83; Tuttle, 1871, pp. 242-243). In his book Confessions of an English Opium-Eater, writer and critic Thomas De Quincey (1860) described such occurrence in a lady as an instance in which a "mighty theatre expanded within her brain" (p. 234). English physician Forbes Winslow also discussed panoramic memory in his textbook On the Obscure Diseases of the Brain, and Disorders of the Mind (1868). These cases, Winslow wrote, presented a "series of striking tableaux of the most minute and remarkable occurrences of their past lives," manifestations said to take place as well "in analogous conditions of [the] morbid and asphyxiated brain" (p. 302). Years later, French philosopher Victor Egger (1896) reviewed cases of panoramic memory in a paper entitled "Le Moi des Mourants" published in the influential journal Revue philosophique de la France et de l'étranger. He argued that they represented a reaction to what the person perceived could be the end of their self.

\section{Deathbed Visions}

The collection also has materials about deathbed visions. Wellknown writer Frances Power Cobbe wrote an essay entitled "The Peak in Darien: The Riddle of Death" (1877, reprinted in 1882) in which, in reference to death-bed visions, she stated that a study of several instances of the experiences of the dying may

seem to indicate that the mind, soul, or self of the expiring person, is not undergoing a process of extinction, but exhibiting such tokens as might be anticipated, were it entering upon a new phase of existence and coming into possession of fresh faculties. (1882, p. 245).

Cobbe presented several cases of such phenomena.

In his book Visions, American physician Edward H. Clarke (1878) had a section about "Visions of the Dying." Clarke explained these 
phenomena as caused by the enhancement of automatic nervous functions when the dying person loses "volition" and "intelligence." As he wrote, the

ganglia of the brain, just before dissolution, sometimes show their automatic power by phenomena, which are unusual .... Old sensitized plates (cells) of memory, emotion, thought, sight, and the like, the accumulated stores of a lifetime, must partake of the general commotion .... Their dynamic state may be temporarily exalted. (pp. 264-265)

Similarly, in his book Natural Causes and Supernatural Seemings, English physician Henry Maudsley (1886, pp. 183-186) saw visions as examples of the weakness of individuals with consumption.

In addition to descriptions of visions taken from the literature, Ernesto Bozzano presented in his paper "Apparitions of Deceased Persons at Death-Beds" (1906) a classification of cases. This classification consisted of visions of persons known to the percipient to have died and seen only by them, similar cases perceived by a single person in which there was no knowledge of death, visions seen by persons other than the dying one, visions related to mediumistic communications, visions perceived only by family members of the dying person, and visions in which the apparitions took place shortly after a death and were seen in the house where the dead body was.

American philosopher and psychical researcher James H. Hyslop (1907, 1919, pp. 140-149) discussed many aspects of death-bed visions. In his 1907 paper "Visions of the Dying," published in the Journal of the American Society for Psychical Research, Hyslop wrote:

If we should find that they bear evidences in any case of supernormal information they would become especially significant. But one of the most important things to study in them would be their relation to instances of hallucination under the same circumstances that had no coincidental value. That is, we need to study their statistical aspects which would require a comparison of the really or apparently coincidental cases with those which are unmistakably hallucinatory and subjective in their origin. For this a large collection is necessary and this can be made without any presumptions regarding their explanation. (pp. 46-47)

A more modern publication along the line suggested by Hyslop in the collection is the book by Karlis Osis and Erlendur Haraldsson, in which there is a report of the most sophisticated deathbed study done so far (Osis \& Haraldsson, 1997). 


\section{Doubles and Apparitions of the Living}

Many $19^{\text {th }}$ century writers believed the concept of the double explained many phenomena, including apparitions of the living and materializations in seances (Brevior, 1874; Coleman, 1865; D'Assier, 1883/1887). A later writer stated:

The double may furnish an explanation of many spiritistic phenomena without having recourse to the spirits of the dead, substituting for these the action of the medium, - the body of the double, or a part of it, acting at a certain distance from the medium's living body, just as this itself would act. Perhaps to the double belong also those more or less incomplete limbs which are seen to emerge from the body (the shoulders or the skirts) of the medium; so also, perchance, with some of those floating hands or arms which exactly resemble those of the medium, so much so that they have given rise to suspicion of deceit (Lombroso, 1909, p. 256).

Others writers discussed a variety of cases and presented a discussion about the existence of a subtle body believed to be able to leave the physical body and to be perceived as an apparition. Books in this regard include Johann Heinrich Jung-Stilling's Theory of Pneumatology (1808/1834), Carl du Prel's Die monistische Seelenlehre (1888), and others (e.g., Delanne, 1899/1904; Fugairon, 1907). English writer Catherine Crowe wrote at length in her popular The Night-Side of Nature (1848/1850) about phenomena showing a spiritual principle that separated from the physical body. In his book, The Spiritual Body, John Charles Earle (1876) affirmed that such a body was not mere theory, but a fact supported by biblical writings.

American spiritualist Samuel B. Brittan wrote the following about apparitions of the living in his book Man and His Relations (1864):

The phenomena are quite likely to occur when the mind is, either partially or entirely, withdrawn from the physical organs of sensation and the outward field of observation. There may be numerous exceptions ... but many persons, whose magneto-spiritual effigies appear at a distance from all corporeal restraints, will be found to have been at the time in some other than a normal, waking state. In profound mental abstraction, or introversion of the faculties-when the soul looks within; when present objects disappear and temporal interests are forgotten; when the mind is centered on things remoteon absent friends, the events of the past and the realities of the future; "in visions of the night when deep sleep falleth on men;" in the palsy of catalepsis; in magnetic coma and other trances; in periods of protracted sickness, which jar and weaken the soul's material connections; when disaster and death are impending and the shadows 
of the immortal world fall on the soul-in all these imperfectly defined physical and psychical conditions, it would seem that the spirit, in some potential sense, leaves the body while it wanders in distant places, or is possibly intromitted to other worlds. (pp. 462463)

Some of the authors discussing doubles or subtle bodies presented the concept as having some physicality, as seen in the writings of Albert de Rochas (1897) and Louis-Sophrone Fugairon (1907). Camille Flammarion (1921/1922) concluded: "It can no longer be doubted that human beings possess fluid phantasms which may, under certain conditions, become visible and tangible" (p. 66).

Good discussions, with case examples, of the variety of apparitions of the living appeared in Edmund Gurney, Frederic W.H. Myers, and Frank Podmore's Phantasms of the Living (1886), in the "Census of Hallucinations" (Sidgwick, Johnson, Myers, Podmore, \& Sidgwick, 1894), as well as in the above mentioned work of Myers (1903). These experiences consisted mainly of apparitions seen at or close to the time when the person represented by the visual or other sensory experience was dying or going through some crisis such as an accident or illness. Other cases were arrival apparitions - perceived just before a person arrived at a place, recurrent apparitions - seen frequently close to or at a distance from the appearer, and apparitions produced intentionally through means such as intense concentration or visualization of a distant person. The following example case took place in 1873 and was reported in 1884. The experiencer's wife confirmed the account and the date of death corresponded to that printed in a newspaper after the fact:

At about 11 o'clock on the night of December 6th, 1873, I had just got into bed, and had certainly not fallen asleep, or even into a doze, when I suddenly startled my wife by a deep groan, and when she asked the reason, I said, "I have just seen my aunt. She came and stood beside me, and smiled with her old kind smile, and disappeared." A muchloved aunt, my mother's sister, was at that time in Madeira, for her health, accompanied by my cousin, her niece. I had no reason to think that she was critically ill at this time, but the impression made upon me was so great that the next day I told her family (my mother among them) what I had seen. Within a week afterwards we heard that she had died on that very night, and, making all allowance for longitude, at about that very time.

When my cousin, who was with her to the last, heard what I had seen, she said, "I am not at all surprised, for she was calling out for you all the time she was dying."

This is the only time I have experienced anything of this nature. I think, perhaps, this story first-hand may interest you. I can only say 
that the vivid impression I received that night has never left me. (Gurney, Myers \& Podmore, 1886, Vol. 2, p. 44).

\section{Apparitions of the Dead}

In addition to the works of Sidgwick et al. (1894) and Myers (1903) mentioned above, the library contains many other discussions of apparitions of the dead such as those published by the SPR (e.g., Myers, 1892; Podmore, 1889; Mrs. H. Sidgwick, 1885). On the basis of the work conducted by the SPR, one of its main workers opened a paper on apparitions stating: "Whatever else a ghost may be, it is probably one of the most complex phenomena in nature" (Myers, 1892, p. 170).

But there are many other books that preceded the above-mentioned work. Among those in Google Books are: Augustin Calmet's The Phantom World (1850), Newton Crosland's Apparitions (1873), Clarence Day's Remarkable Apparitions, and Ghost-Stories (1848), John Ferriar's Essay Towards a Theory of Apparitions (1813), William Harrison's Spirits Before Our Eyes (1879), Samuel Hibbert's Sketches of the Philosophy of Apparitions (1825), T. M. Jarvis's Accredited Ghost Stories (1823), Charles Ollier's Fallacy of Ghosts, Dreams, and Omens (1848), Joseph Taylor's Apparitions, or the Mystery of Ghosts, Hogoblins, and Haunted Houses (1815), and James Thatcher's An Essay on Demonology, Ghosts, and Apparitions and Popular Superstitions (1831). One of these authors wrote:

Nearly all the tales of Ghosts and Apparitions, which are familiar in France, in Spain, in Germany, in Italy, and in England, are accompanied with circumstances so similar that they might almost be regarded as different accounts of the same event. Nearly all of them are supposed to have taken place at the moment of the soul's separation from the body. The spirit seems to have followed the direction of the dying thoughts, and to have stood before the being who was dearest to its affections before it was removed for ever from the interests of the earth, to share the retributions of its immortality.

Narrations of this kind are so common in every country, in every neighbourhood, I had almost said in every family, that there is scarcely a single individual who is not acquainted with some instance of this peculiar kind of preternatural event, which has fallen under his more immediate knowledge, which has happened to persons of credit and veracity, and which, however he may assert his incredulity, will involuntarily impair the force and the conviction of his philosophical unbelief. It is extraordinary that mankind should so generally agree in 
imagining the appearance of the departed spirit to be possible and frequent; it is extraordinary they should prescribe the same particular moment for its appearance; it is extraordinary they should fix upon a moment when the dreams of the fancy could have no basis to work upon; it is extraordinary that they should not wait the authentication of the death, before they held imaginary communication with the spirit. It is still more extraordinary that these anticipations should so often have been corroborated by the event, and confirmed by their exact coincidence with the truth (Jarvis, 1823, pp. 6-8).

\section{Descriptions and Visions of Death}

The literature in this digital library presents other interesting materials related to death. This material includes observations of the exteriorization of the spirit by deathbed observers. In clairvoyant Andrew Jackson Davis's book The Great Harmonia (1850, pp. 165-172), he described one such observation. Sophia de Morgan presented somewhat similar visions in the ninth chapter of From Matter to Spirit (1863):

I was myself once standing with a person who had sometimes the gift of spiritual vision, beside a bed on which lay one whose life was departing. The breathing was ceasing slowly when I noticed a thin white mist which seemed to rise two or three inches above the bed. My companion appeared also to be looking at something. Her eyes, which always had a strange glitter when they encountered any object unseen by others, were raised gradually from the recumbent form to the top of the bed; then, returning, seemed to rest half-way between, gazing, as far as I could see, on vacancy. This earnest gaze lasted more than a minute. I looked at her enquiringly, but she did not speak. She told me a few minutes after what she had seen, thus:-

'I was looking at a mist which seemed to be rising from the bed, and which I have noticed some time, when my attention was drawn upwards, and I saw a pillar of light, between sunshine and moonlight, rising three or four feet. Within this was a still brighter light, becoming more brilliant at the centre; and from the centre to the circumference, from within outwards, it was all working together with intense rapidity. I saw it once again, but slightly afterwards, just as the last breath was drawn. It seemed then to pass off by the top of the bed.' The seer has been a trusted friend of my own for many years; her character for truthfulness is quite above suspicion (p. 128).

The idea of something leaving the body at death was at the core of Duncan MacDougall's (1907) weighing experiments with dogs and human beings. According to MacDougall, 
It is unthinkable that personality and consciousness continuing personal identity should exist, and have being, and yet not occupy space .... Since therefore it is necessary to the continuance of conscious life and personal identity after death, that they must have for a basis that which is space occupying or substance, the question arises, has this substance weight; is it ponderable? (pp. 237-238)

In a friendly exchange with MacDougall, psychical researcher Richard Hodgson questioned whether such a physicalistic conception of survival was needed; their private correspondence was published in the Journal of the American Society for Psychical Research (MacDougall \& Hodgson, 1907). Google Books also includes other individuals' critiques of MacDougall's work (Carrington, 1907; O’Malley, 1907).

In his Experimental Investigations of the Spirit Manifestations (1855, pp. 101-113), an early classic of American spiritualism, American chemist Robert Hare recorded mediumistic communications about "spiritual birth." These were descriptions the "deceased" gave of the separation of their spirit from the physical body at death. In one such description the mediumistic communicator stated that

when the vital cord which bound me to the physical body was parted, I experienced a full consciousness of my personality. I enjoyed perfect freedom from pain and sickness, and an unwonted degree of strength and buoyancy of spirit; sensations of the most exalted character took possession of me, and a holy calm pervaded the sanctuary of my soul. It was not, however, until I saw my body lying upon the bed, that the true nature of my situation flashed across my mind. (p. 111)

\section{Survival of Death}

Whereas much of the above mentioned material was embedded in the notion of survival of death, the Google Books collection contains many explicit discussions of the topic. Some general ones are Minot Savage's Life Beyond Death (1899), Robert Thompson's The Proof of Life After Death (1902), Emily Bates's Do the Dead Depart? (1908), Edward Clodd's The Question: "If a Man Die, Shall He Live Again?" (1918), and Hyslop's Contact with the Other World (1919). One of the best known and most influential works on the topic was Myers' above mentioned Human Personality and Its Survival of Bodily Death (1903). Myers wrote about apparitions and mediumship: 
(a) In the first place, they prove survival pure and simple; the persistence of the spirit's life as a structural law of the universe; the inalienable heritage of each several soul.

(b) In the second place, they prove that between the spiritual and the material worlds an avenue of communication does in fact exist; that which we call the despatch and the receipt of telepathic messages, or the utterances and the answer of prayer and supplication.

(c) In the third place, they prove that the surviving spirit retains, at least in some measure, the memories and the loves or earth. Without this persistence of love and memory should we be in truth the same? To what extent has any philosophy or any revelation assured us hereof till now? (Vol. 2, pp. 256-257).

Much of relevance to the history of the idea of survival coming from the $19^{\text {th }}$ century are the various books in the collection about early spiritualism and spiritism. Some of them include Adin Ballou's An Exposition of Views Respecting the Principal Facts, Causes and Peculiarities Involved in Spirit Manifestations (1853), Samuel Brittan and B. W. Richmond's A Discussion of the Facts and Philosophy of Ancient and Modern Spiritualism (1853), John W. Edmonds and George T. Dexter's Spiritualism (1853-1855), Eliab W. Capron's Modern Spiritualism (1855), Robert Hare's Experimental Investigation of the Spirit Manifestations (1855), Allan Kardec's Le livre des esprits (1857), and Robert D. Owen's Footfalls on the Boundary of Another World (1860). The latter wrote about the action of spiritual beings:

As to the proofs of the agency upon earth of these Invisibles, I rest them not on any one class of observations set forth in this volume, not specially on the phenomena of dreaming, or of unexplained disturbances, or of apparitions whether of the living or the dead, or of what seem examples of ultramundane retribution or indications of spiritual guardianship, but upon the aggregate and concurrent evidence of all these. It is strong confirmation of any theory that proofs converging from many and varying classes of phenomena unite in establishing it. (pp. 508-509)

The virtual library also has works about old ideas about death, the afterworld, and similar topics. An example is William Rounseville Alger's A Critical History of the Doctrine of a Future Life (1864). This book has several sections covering introductory views (four chapters; e.g., theories about destination of the soul), ideas of specific groups (12 chapters; e.g., Hebrew ideas), New Testament ideas (eight chapters; e.g., Paul's doctrine), Christian ideas (three chapters; e.g., medieval 
ideas), and various aspects of the idea of the future life (nine chapters; e.g., metempsychosis). The book includes an appendix by Ezra Abbot about "Literature of the Doctrine of a Future Life" with sections about the nature, destiny, and future life of the soul. An appendix in the bibliography includes a list of books about spiritualism.

Another useful work is William Howitt's The History of the Supernatural (1863). This two-volume work includes chapters about psychic phenomena and spiritual ideas in chapters covering the topics from antiquity to the development of spiritualism. In addition to discussions of ideas from specific countries and from the Bible, the author focused on ancient Egypt, Greece, and Rome, among many other countries. Referring to the action of a spiritual world Howitt argued: "There is no part of human history, or human literature, which does not abound in the plainest demonstrations of this influence" (Vol. 1, p. 1).

\section{Concluding Remarks}

This article contains but a small sample of the materials of historical interest available in this digital library. In fact, many other relevant topics are represented in Google Books, among them a variety of materials about mental mediumship, as seen in my bibliography of available references about a particular medium (Alvarado, 2009b). Because the collection keeps growing as more materials get scanned I advise prospective users of the library to check the holdings periodically for relevant materials. Such explorations need not to be confined to specific phenomena, but may include wider topics and areas likely to generate materials covering one's subject matter. Careful searches performed inside documents about mesmerism, psychology, philosophy, psychiatry, psychical research, religion, and spiritualism, among other topics, can reveal much relevant material about death, dying, out-of body phenomena, and issues such as survival of death.

The literature discussed here shows many similarities to current concerns in the field of near-death studies, as seen in contemporary discussions of OBEs, NDEs, and mediumship. But interested readers can also learn about topics that are not commonly discussed in the current literature, among them McDougall's weighing studies, the concept of the double, and visions of death.

As mentioned before, knowledge of this literature can have practical benefits for current researchers. In addition, to practical concerns 
related to research and theory, these writings can do no less that expand a general understanding of the history of these topics.

\section{References}

Alger, W. R. (1864). A critical history of the doctrine of a future life. Philadelphia, PA: George W. Childs.

Alvarado, C. S. (2005). Ernesto Bozzano and the phenomena of bilocation. Journal of Near-Death Studies, 23, 207-238.

Alvarado, C. S. (2007a). Bibliography of books and articles about mesmerism, spiritualism, psychical research, and related topics in Google Book Search. Psypioneer, 3, 113-120, Retrieved from http://www.woodlandway.org/PDF/PP3.5May07..pdf

Alvarado, C. S. (2007b). Online historical materials about psychic phenomena. Journal of Scientific Exploration, 21, 607-615.

Alvarado, C. S. (2008a). Mesmerism online: A bibliographic review. Australian Journal of Clinical and Experimental Hypnosis, 36, 115-120.

Alvarado, C. S. (2008b). Note on online books and articles about the history of dissociation. Journal of Trauma and Dissociation, 9, 107-118.

Alvarado, C. S. (2009a). Early and modern developments in the psychological approach to out-of-body experiences. In C. D. Murray (Ed.), Psychological scientific perspectives on out-of-body and near-death experiences (pp. 1-22). New York: Nova Science.

Alvarado, C. S. (2009b). Leonora E. Piper online: Some Web resources. Psypioneer, 5, 87-92, Retrieved from http://www.woodlandway.org/PDF/PP5.3March09..pdf

Alvarado, C. S. (2009c). The spirit in out-of-body experiences: Historical and conceptual notes. In B. Batey (Ed.), Spirituality, science and the paranormal (pp. 3-19). Bloomington, CT: Academy of Spirituality and Paranormal Studies.

Arber, E. (Ed.). (1869). The revelation of the monk Evesham. London, England: n.p.

Ballou, A. (1853). An exposition of views respecting the principal facts, causes and peculiarities involved in spirit manifestations (2nd ed.). Boston, MA: Bela Marsh.

Bates, E. K. (1908). Do the dead depart?. New York, NY: Dodge.

Besant, A. (1892). The seven principles of man (Theosophical Manuals No. 1). London, England: Theosophical Publishing Society.

Bozzano, E. (1906). Apparitions of deceased persons at death-beds. Annals of Psychical Science, 3, 67-100.

Brevior, T. (1874). Spiritual problems.-Materialisation of spirit forms.-The double. Spiritual Magazine, 9(n.s.), 152-160.

Brierre de Boismont, A. (1853). Hallucinations: Or, the rational history of apparitions, visions, dreams, ecstasy, magnetism, and somnambulism (1st American, from the 2nd French ed.). Philadelphia, PA: Lindsay and Blakiston.

Brittan, S. B. (1864). Man and his relations: Illustrating the influence of the mind on the body. New York, NY: W. A. Townsend.

Brittan, S. B., \& Richmond, B. W. (1853). A discussion of the facts and philosophy of ancient and modern spiritualism. New York, NY: Partridge \& Brittan.

Cahagnet, L. A. (1851). The celestial telegraph (1st American ed.). New York, NY: J. S. Redfield.

Calmet, A. (1850). The phantom world (2 vols.). London, England: Richard Bentley.

Capron, E. W. (1855). Modern spiritualism: Its facts and fanaticisms, its consistencies and contradictions. Boston, MA: Bela Marsh.

Carrington, H. (1907). On Dr. MacDougall's experiments. Journal of the American Society for Psychical Research, 1, 276-283. 
Carrington, H. (1920). Your psychic powers and how to develop them. New York, NY: Dodd, Mead.

Clarke, E. H. (1878). Visions: A study of false sight. Boston, MA: Houghton, Osgood.

Clarke, J. B. B. (Ed.). (1833). An account of the infancy, religious and literary life of Adam Clarke, LL.D., F.A.S. New York, NY: D. Appleton.

Clodd, E. (1918). The question: "If a man die, shall he live again?". New York, NY: Edward J. Clode.

Cobbe, F. P. (1877). The peak in Darien: The riddle of death. Littell's Living Age, 19(s.5), 374-379.

Cobbe, F. P. (1882). The peak in Darien, with some other inquiries touching concerns on the soul and the body. Boston, MA: Geo. H. Ellis.

Coleman, B. (1865). Passing events.-The spread of spiritualism. Spiritual Magazine, 6, $110-128$.

Crosland, N. (1873). Apparitions. London, England: Trübner.

Crowe, C. (1850). The night-side of nature. New York, NY: J. S. Redfield. (Original work published in 1848)

D’Assier, A. (1887). Posthumous humanity: A study of phantoms. London, England: George Redway. (Originally published in French, 1883)

Davis, A. J. (1850). The great harmonia (Vol. 1). Boston, MA: Benjamin B. Mussey.

Day, C. S. (1848). Remarkable apparitions, and ghost-stories. New York, NY: Wilson.

Delanne, G. (1904). Evidence for a future life. London, England: Philip Wellby. (Original work published 1899)

Denton, W. (1872). Radical discourses on religious subjects. Boston, MA: William Denton.

De Morgan, S. (1863). From matter to spirit. London, England: Longman, Green, Longman, Roberts, \& Green.

De Quincy, T. (1860). Confessions of an English opium-eater. Boston, MA: Ticknor and Fields.

De Rochas, A. (1897). Les expériences de Choisy-Yvrac (près Bordeaux) du 2 au 14 octobre 1896 [The experiments at Choisy-Yvrac (near Bordeaux) from October 2 to 14, 1896]. Annales des Sciences Psychique, 7, 6-28.

Didier, A. (1856). Le sommeil magnétique expliqué par le somnambule Alexis en état de lucidité [Magnetic sleep explained by the somnambule Alexis in the lucid state]. Paris, France: R. Dentu.

Du Prel, C. (1888). Die monistische Seelenlehre [The monistic doctrine of the mind]. Leipzig, Germany: Ernst Günthers.

Durville, H. (1908a). Experimental researches concerning phantoms of the living. Annals of Psychical Science, 7, 335-343.

Durville, H. (1908b). New experiments with phantoms of the living. Annals of Psychical Science, 7, 464-470.

Durville, H. (1908c). Phénomènes observés dans le dédoublement du corps humain [Phenomena observed during the doubling of the human body]. L'initiation, 80, 210-222.

Earle, J. C. (1876). The spiritual body (enlarged ed.). London, England: Longmans, Green.

Edmonds, J. W., \& Dexter, G. T. (1853-1855). Spiritualism (2 vols.). New York, NY: Partridge \& Brittan.

Egger, V. (1896). Le moi des mourants [The self of the dying]. Revue Philosophique de la France et de L'étranger, 21, 26-38.

Engelbrecht, J. (1780). The divine visions of John Engelbrecht (Vol. 1). Northhampton, England: Thomas Dicey.

Ferriar, J. (1813). Essay towards a theory of apparitions. London, England: Caddell and Davies. 
Flammarion, C. (1922). Death and its mystery: At the moment of death. New York, NY: Century. (Original work published 1921)

Fugairon, L. S. (1907). La survivance de l'ame ou, l'mort et la renaissance chez les êtres vivants [The survival of the soul or, death and rebirth in human beings]. Paris, France: Librairie du Magnétisme.

Gibs, J. A. (Ed.). (1847). The Venerable Bede's ecclesiastical history of England. London, England: Henry G. Bohn.

Gougenot de Mousseaux, H. R. (1864). Les hauts phénomènes de la magie [The high phenomena of magic]. Paris, France: Henri Plon.

Gurney, E., Myers, F. W. H., \& Podmore, F. (1886). Phantasms of the living (2 vols.). London, England: Trübner.

Haddock, J. W. (1851). Somnolism \& psycheism. London, England: James S. Hodson.

Hare, R. (1855). Experimental investigation of the spirit manifestations. New York, NY: Partridge \& Brittan.

Harrison, W. H. (1879). Spirits before our eyes. London, England: W. H. Harrison.

Hibbert, S. (1825). Sketches of the philosophy of apparitions (2nd enlarged ed.). Edinburgh, Scotland: Oliver \& Boyd.

Hill, J. A. (1918). Man is a spirit: A collection of spontaneous cases of dream, vision, and ecstasy. London, England: Cassell.

Home, D. D. (1863). Incidents in my life. New York, NY: Carleton.

Howitt, W. (1863). The history of the supernatural (2 vols.). London, England: Longman, Green, Longman, Roberts, \& Green.

Hyslop, J. H. (1907). Visions of the dying. Journal of the American Society for Psychical Research, 1, 45-55.

Hyslop, J. H. (1919). Contact with the other world. New York, NY: Century.

Jarvis, T. M. (1823). Accredited ghost stories. London, England: J. Andrews.

Jung-Stilling, J. H. (1834). Theory of pneumatology. London, England: Longman, Rees, Orman, Brown, Green, and Longman. (Original work published 1808)

Kardec, A. (1857). Le livre des esprits [The book of spirits]. Paris, France: E. Dentu.

Leadbeater, C. W. (1895). The astral plane: Its scenery, inhabitants and phenomena. London, England: Theosophical Publishing House.

Life of the Rev. William Tennent. (1848). New York, NY: Robert Carter.

Lombroso, C. (1909). After death-what?. Boston, MA: Small, Maynard.

MacDougall, D. (1907). Hypothesis concerning soul substance together with experimental evidence of the existence of such substance. Journal of the American Society for Psychical Research, 1, 237-244.

MacDougall, D., \& Hodgson, R. (1907). Correspondence. Journal of the American Society for Psychical Research, 1, 263-275.

Maudsley, H. (1886). Natural causes and supernatural seemings. London, England: Kegan, Paul, Trench.

Morin, A. S. (1860). Du magnétisme et des sciences occultes [Magnetism and occult sciences]. Paris, France: Germer Baillière.

Myers, F. W. H. (1892). On indications of continued terrene knowledge on the part of phantasms of the dead. Proceedings of the Society for Psychical Research, 8, 170-252.

Myers, F. W. H. (1903). Human personality and its survival of bodily death (2 vols.). London, England: Longmans, Green.

Olcott, H. S. (1895). Old diary leaves: The true story of the Theosophical Society. New York, NY: G. P. Putnam's Sons.

Ollier, C. (1848). Fallacy of ghosts, dreams, and omens. London, England: Charles Ollier.

O'Malley, A. (1907). Is the vital principle ponderable? American Medicine, 13, 653-658.

Osis, K., \& Haraldsson, E. (1997). What they saw ... at the hour of death ( ${ }^{\text {rd }}$ ed.). Norwalk, CT: Hastings House.

Owen, R. D. (1860). Footfalls on the boundary of another world. Philadelphia, PA: J. B. Lippincott. 
Piobb, P. (1908). L’année occultiste et psychique. Paris, France: H. Daragon.

Pliny the Edler. (1890). The natural history of Pliny (Vol. 2). London, England: George Bell \& Sons.

Podmore, F. (1889). Phantasms of the dead from another point of view. Proceedings of the Society for Psychical Research, 6, 229-313.

Podmore, F. (1894). Apparitions and thought-transference. London, England: Walter Scott.

Richet, C. (1887). L'homme et l' intelligence (2nd ed.) [Man and intelligence]. Paris, France: Félix Alcan.

Rogo, D. S. (1978). Research on deathbed experiences: Some contemporary and historical perspectives. Parapsychology Review, 9(1), 20-27.

Savage, M. J. (1899). Life beyond death. New York, NY: G. P. Putnam's Sons.

Schilleto, A. R. (Ed. and Trans.). (1888). Plutarch's morals: Ethical essays. London, England: George Bell and Sons.

Scott, J. L. (1859). Scenes beyond the grave: Trance of Marietta Davis (17th ed.). Dayton, OH: Stephen Deuel.

Sidgwick, H., Johnson, A., Myers, F. W. H., Podmore, F., \& Sidgwick, E. M. (1894). Report on the Census of Hallucinations. Proceedings of the Society for Psychical Research, 10, 25-422.

Sidgwick, Mrs. H. (1885). Notes on the evidence, collected by the Society, for phantasms of the dead. Proceedings of the Society for Psychical Research, 3, 69-150.

Sidgwick, Mrs. H. (1891). On the evidence for clairvoyance. Proceedings of the Society for Psychical Research, 7, 30-99.

Stead, W. T. (1896). Two doubles I have seen. Borderland, 3, 24-36.

Taylor, J. (1815). Apparitions, or the mystery of ghosts, hogoblins, and haunted houses. London, England: Lackington, Allen.

Thatcher, J. (1831). An essay on demonology, ghosts, and apparitions and popular superstitions. Boston, MA: Carter and Hendee.

Thompson, R. J. (Ed.). (1902). The proof of life after death. Chicago, IL: Robert J. Thompson.

Thorpe, B. (Eds.). (1846). The homilies of the Anglo-Saxon Church (Vol. 3). London, England: Aelfic Society.

Tuttle, H. (1871). Arcana of spiritualism. Boston, MA: Adams.

Wiltse, A. S. (1889). A case of typhoid fever with subnormal temperature and pulse. St. Louis Medical and Surgical Journal, 57, 355-364.

Winslow, F. (1868). Obscure diseases of the brain and mind (2nd American ed. from the 3rd English ed.). Philadelphia, PA: Henry C. Lea.

Zaleski, C. (1987). Otherworld journeys: Accounts of near-death experience in medieval and modern times. New York, NY: Oxford University Press. 